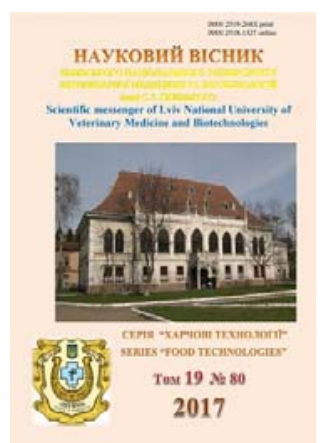

Науковий вісник Львівського національного університету ветеринарної медицини та біотехнологій імені С.З. Гжицького

Scientific Messenger of Lviv National University of Veterinary Medicine and Biotechnologies

doi:10.15421/nvlvet8019

ISSN 2519-268X print

ISSN $2518-1327$ online

$\underline{\text { http://nvlvet.com.ua/ }}$

УдК 637.1

\title{
Розроблення технології моцарелли із застосуванням різних способів зсідання білків
}

\author{
О.Й. Цісарик, Л.Я. Мусій, І.М. Сливка, Т.Ф. Молокус \\ tsisaryk_o@yahoo.com,musiyluba@ukr.net, slyvka.88@ukr.net
}

Львівський національний університет ветеринарної медицини та біотехнологій імені С.3. Гжицького, вул. Пекарська, 50, м. Львів, 79010, Украӥна

\begin{abstract}
Метою досліджень було розробити технологію м'якого сиру «Моцарелла» із використанням різних способів зсідання білків та порівняти ефективність їх застосування у його технології. Молочну сировину для виробництва сиру заготовляли y березні 2017 р. Сир «Моцарелла» виготовляли з незбираного молока, яке аналізували на відповідність вимогам діючого Стандарту.Для сичужного зсідання молока використовували телячий сичужний фермент фірми «Хр. Хансен, Украӥна» CHY-тах, заквашувальну культуру прямого внесення фірми «Хр. Хансен, Украӥна» RSF-742, калій хлористий у вигляді $1 \%$ розчину та лимонну кислоту у вигляді 1,5\% розчину.Для дослідження було виготовлено два зразки сиру (із 3-разовим повторенням): зразок 1 - зсідання білків за участю лимонної кислоти (нормалізована суміш + сичужсий фермент + лимонна кислота); зразок 2 - зсідання білків за участю заквамувальної культури прямого внесення (нормалізована суміш + сичужний фермент + заквашувальну культура + хлористий кальиій). Тривалість сичужного зсідання молока визначали від моменту внесення ферментів у молочну основу до утворення щільного згустку. У отриманих згустках визначали синеретичні властивості, вимірюючи об'єм виділеної сироватки через кожні 10 хв. протягом 1 год. У готовому продукті визначали вихід сиру, органолептичні та фізико-хімічні показники.

Встановлено, щзо використання лимонної кислоти призводить до скорочення технологічного процесу виробництва продукту та до збільшення виходу сиру. Однак, згідно органолептичної оцінки зразок із використанням лимонної кислоти характеризувався вираженим сирним, без сторонніх присмаків та запахів, властивий м'якому свіжому сиру смаком $і$ запахом та вищим вмістом вологи. Гіршими органолептичними показниками характеризувався зразок 3 використаннямзаквашувальної культури прямого внесення RSF-742, однак під час зберіганнязразок характеризувався крашими фізико-хімічними показниками.

Ключові слова: м'який сир, Моиарелла, технологія, закваска, лимонна кислота, зсідання білків, тривалість зсідання, синеретичні властивості, вихід сиру, органолептичні показники.
\end{abstract}

\section{Разработка технологии моцареллы с применением различных способов свертывания белков}

О.И. Цисарик, Л.Я. Мусий, И.М. Сливка, Т.Ф. Молокус

tsisaryk_o@yahoo.com, musiyluba@ukr.net,slyvka.88@ukr.net

Львовский национальный университет ветеринарной медицины и биотехнологий имени

С.3. Гжицкого, ул. Пекарская, 50, г. Львов, 79010, Украина

\begin{abstract}
Целью исследований было разработать технологию мягкого сыра «Моцарелла» с использованием различных способов свертывания белков и сравнить эффективность их применения в его технологии. Молочное сырье для производства сыра заготавливали в марте 2017 Сыр «Моцарелла» изготавливали из иельного молока, анализировали на соответствие требованиям действующего стандарта. Для сычужного свертывания молока использовали телячий сычужный фермент фирмы «Хр. Хансен, Украина» СНY-тах, заквасочных культуру прямого внесения фирмы «Хр. Хансен, Украина» RSF-742, калий в виде 1\% раствора и лимонную кислоту в виде 1,5\% раствора. Для исследования было изготовлено два образиа сыра (с 3-
\end{abstract}

\section{Citation:}

Tsisaryk, O.Y., Musiy, L.Y., Slyvka, I.M., Molokus, T.F. (2017). Development of mozzarella technology using different methods of protein coagulation. Scientific Messenger LNUVMB, 19(80), 93-98. 
разовым повторением): образеи 1 - свертывания белков с участием лимонной кислоты (нормализованная смесь + сычужный фермент + лимонная кислота); образец 2 - свертывания белков с участием заквасочной культуры прямого внесения (нормализованная смесь + сычужный фермент + заквасочная культура + хлористый кальций). Продолжстельность сычужного свертывания молока определяли с момента внесения ферментов в молочную основу для образования плотного сгустка. В полученных сгустках определяли синеретические свойства, измеряя объем выделенной сыворотки через каждые 10 мин. в течение 1 ч. В готовом продукте определяли выход сыра, органолептические и физико-химические показатели.

Установлено, что использование лимонной кислоты приводит к сокращению технологического процесса производства продукта и к увеличению выхода сыра. Однако, согласно органолептической оценки образец с использованием лимонной кислоты характеризовался выраженным сырным, без посторонних привкусов и запахов, свойственный мягком свежем сыра вкусом и запахом и высоким содержанием влаги. Худшими органолептическими показателями характеризовался образец с использованием заквасочной культуры прямого внесения RSF-742, однако во время хранения образеи характеризовался лучшими физико-химическими показателями.

Ключевые слова: мягкий сыр, Моцарелла, технология, закваска, лимонная кислота, свертывания белков, продолжительность свертывания, синеретические свойства, выход сыра, органолептические показатели.

\title{
Development of mozzarella technology using different methods of protein coagulation
}

\author{
O.Y. Tsisaryk, L.Y. Musiy, I.M. Slyvka, T.F. Molokus \\ tsisaryk_o@yahoo.com,musiyluba@ukr.net, slyvka.88@ukr.net \\ Stepan Gzhytskyi National University of Veterinary Medicine and Biotechnologies Lviv, \\ Pekarska Str., 50, Lviv, 79010, Ukraine
}

\begin{abstract}
The aim of the research was to develop the technology of soft cheese «Mozzarella» using different methods of protein synthesis and compare the effectiveness of their application in its technology. Dairy raw materials for cheese production were harvested in March 2017. Mozzarella cheese was made from whole milk, which was analyzed for compliance with the requirements of the current Standard. For the sticky mixing of milk were used calf serum enzyme firm «Chr. Hansen, Ukraine» CHY-max, the fermentation culture of the direct introduction of the company «Chr. Hansen, Ukraine» RSF-742, potassium chloride in the form of $1 \%$ solution and citric acid in the form of 1.5\% solution. Two samples of cheese (with a 3-time repetition) were made for the study: Sample 1-protein mixing with citric acid (normalized mixture + sifted enzyme + citric acid); Sample 2 - protein mixing with the direct introduction of the fermentation culture (normalized mixture + sifted enzyme + yeast culture + calcium chloride). The duration of slicer milk was determined from the moment the enzymes were introduced into the milk basis until a dense bunch was formed. In the resulting clusters, the synergetic properties were determined by measuring the amount of serum isolated every 10 min. within 1 year. The finished product determined the yield of cheese, organoleptic and physico-chemical parameters.

It is established that the use of citric acid leads to a reduction in the technological process of product production and to increase the yield of cheese. However, according to an organoleptic assessment, the sample using citric acid was characterized by pronounced cheese, without foreign flavors and odors, characterized by a soft fresh cheese flavor and smell and a higher moisture content. The worse organoleptic parameters were characterized by a sample using the direct fermentation culture of RSF-742, but during storage, the specimen was characterized by better physico-chemical characteristics.
\end{abstract}

Key words: soft cheese, mozzarella, technology, culture, citric acid, protein mixes, duration of seeding, synergetic properties, cheese yield, organoleptic parameters.

\section{Вступ}

Сироробна галузь є однією 3 найдинамічніших споживчих сегментів зі стійким зростанням обсягів виробництва і споживання. Проте аналіз вітчизняного ринку м'яких сирів показав тенденцію до підвищення споживання, в основному, за рахунок сирів імпортного виробництва, через обмежений вітчизняний асортимент сирів цього виду. Серед м'яких сирів імпортного виробництва популярністю у споживачів користуються Моцарелла, Рікотта, Маскарпоне (Італія) (Kalmykova, 2015).

На сучасному етапі сироробства широкого застосування набуло використання культур прямого внесення, які забезпечують високий рівень стандартизації процесу ферментування та якості готового продукту. Особливим попитом користуються бактеріальні препарати з наявністю лактобацил, які наділені протеолітичною активністю, оскільки здатність нагромадження низькомолекулярних азотовмісних сполук є домінуючим у формуванні смакових нот сиру (Soda et al.,
2000). Проте використання культур прямого внесення вимагає вдосконалення окремих технологічних режимів виробництва продукту. Відомо, що всі процеси, які відбуваються під час виробництва сиру, тісно взаємопов'язані між собою, i, практично кожний попередній виробничий етап з відповідними параметрами $є$ базисом для наступних (Tkachenko and Skrypnichenko, 2016; Musiy et al., 2017).

Моцарелла (іт. Mozzarella) - молодий сир італійського походження, родом з регіону Кампанія. Класична моцарелла (Mozzarella di bufala campana) виготовляється 3 молока чорних буйволиць, однак у продажі практично завжди присутня моцарелла 3 коров'ячого молока. Цей сир продають у вигляді білих кульок, які зберігають у розсолі, оскільки термін його зберігання невеликий. Також моцарелла буває твердою, як звичайний сир, який використовують для гарячих страв. Виготовляється і копчена моцарелла (Mozzarella affumicata) (Shergina, 2009).

Висока харчова цінність сиру зумовлена не лише великою кількістю білка, молочного жиру, мінераль- 
них солей, вітамінів, а й тим, що засвоюваність білків і жиру, що містяться в сирі, досягає 95-97\%.

Виробництво сиру починається 3 того, що молоко заквашують термофільною молочнокислою культурою і згортають сичужним ферментом (іноді з додаванням хлориду кальцію; також при прискореному способі допускається замість молочнокислих культур використовувати розчин лимонної кислоти). Здійснюють розрізання згустку з отриманням зерна розміром 20-30 мм. Усувають частину сироватки, частину 3 якої підігрівають до температури $46{ }^{\circ} \mathrm{C}$ і знову додають до сирного зерна до тих пір, поки його температура не досягне $36{ }^{\circ} \mathrm{C}$. Цей процес - чедеризація, при якому знижується активна кислотність до 4,9 од. $\mathrm{pH}$, змінюється сольова рівновага - утворюється лактат кальцію, який на відміну від колоїдного фосфату кальцію є розчинною сіллю. Це забезпечує надання пластичності і еластичності сирному тісту. Після визрівання зерна його розтягують у киплячій воді. Процес вважається закінченим, коли сир набуває гомогенної консистенції, а поверхня стає блискучою. Після цього відрізають чи відривають шматки, формують сир різної форми (кульки, косички) і поміщають в холодний насичений розчин кухонної солі. Процес формування називається mozzatura (відрізати) - звідси і назва сиру. Сироватка при виробництві сиру моцарелла використовується для приготування сиру рікотта (Gudkov, 2004; Mironenko and Usatjuk, 2015). Після формування, кульки занурюють в холодну воду, а після охолодження - солять, найчастіше у розсолі.

Центральною технологічною операцією при виробництві сирів $є$ зсідання білків, тому одним із напрямів удосконалення традиційних технологій м'яких сирів є підбір способів коагуляції і зсідання білків (Bannikova et al., 1987).

Метою нашої роботи було розробити технологію м'якого сиру «Моцарелла» із використанням різних способів зсідання білків та порівняти ефективність їх застосування у його технології. Для зсідання білківмолока було використано два способи: внесення заквашувальної культури прямого внесення і розчину лимонної кислоти.

\section{Матеріал і методи досліджень}

Експериментальні дослідження розроблення технології м'якого сиру «Моцарелла» із використанням різних молокозсідальних ферментів проводились у лабораторії кафедри технології молока i молочних продуктів Львівського національного університету ветеринарної медицини та біотехнологій імені С.3. Гжицького. Молочну сировину для виробництва для виробництва сиру заготовляли у березні 2017 р. Сир «Моцарелла» виготовляли 3 незбираного молока, яке аналізували на відповідність вимогам діючого Стандарту «Молоко коров’яче незбиране. Вимоги при закупівлі» (ДСТУ 3662:1997).

Для сичужного зсідання молока використовували телячий сичужний фермент фірми «Хр. Хансен, Україна» CHY-max, заквашувальну культуру прямого внесення фірми «Хр. Хансен, Україна» RSF-742, калій хлористий у вигляді $1 \%$ розчину та лимонну кислоту у вигляді $1,5 \%$ розчину.

Сичужний фермент CHY-MAX розчиняли у дистильованій воді у розрахунку 1 г на 100 л молока.

Як заквашувальну культуру використано препарат прямого внесення RSF-742 («Хр. Хансен, Україна»), що містить у своєму складі такі штами молочнокислих бактерій: Lactococcus lactis subsp. cremoris, Lactococcus lactis subsp. lactis, Streptococcus thermophilus, Lactobacillus helveticus.

Для дослідження було виготовлено два зразки сиру (з триразовим повторенням):

- зразок 1 - зсідання білків за участю лимонної кислоти (нормалізована суміш + сичужний фермент + лимонна кислота);

- зразок 2 - зсідання білків за участю заквашувальної культури прямого внесення (нормалізована суміш + сичужний фермент + заквашувальна культура + хлористий кальцій).

Тривалість сичужного зсідання молока визначали від моменту внесення ферментів у молочну основу до утворення щільного згустку. У отриманих згустках визначали синеретичні властивості, вимірюючи об'єм виділеної сироватки через кожні 10 хв. протягом 1 год. У готовому продукті визначали вихід сиру, органолептичні, фізико-хімічні та мікробіологічні показники.

\section{Результати та їх обговорення}

Для виробництва м'якого сиру «Моцарелла» із використанням різних способів зсідання білків використовували молоко коров'яче незбиране згідно ДСТУ 3662-97 першого гатунку. Технологічна схема виробництва м'якого сиру «Моцарелла» при використанні для зсідання білків молока лимонної кислоти у вигляді $1,5 \%$ розчину представлена на рисунку 1.

Охолоджене молоко поступало у ванни, де його нормалізували знежиреним молоком (м. ч. ж. 0,05\%) до масової частки жиру у нормалізованій суміші $3,1 \%$. У охолоджену нормалізовану суміш вносили лимонну кислоту у вигляді $1,5 \%$ розчину у розрахунку 1,5 г на 1 л нормалізованої суміші. Перемішували суміш протягом 1 хв. і підігрівали до температури $32 \pm 1{ }^{\circ} \mathrm{C}$. У підігріте молоко вносили молокозсідальний фермент CHY-max у розрахунку 1 г на 100 л нормалізованої суміші. Молокозсідальний фермент попередньо розчиняли у холодній дистильованій воді. Суміш перемішували 30 с і залишали у спокої для сичужного зсідання. Утворений сирний згусток розрізали на кубики розміром $2 \times 2$ см. Сирний згусток разом із сироваткою підігрівали до температури $43 \pm 1{ }^{\circ} \mathrm{C}$ для кращого іiі відділення і визрівання сирного зерна.

Сирне зерно витягували і відділяли його від сироватки. Сироватку нагрівали до температури $85 \pm 1{ }^{\circ} \mathrm{C}$ і відірвавши шматочок від сирного згустку, занурювали його у гарячу сироватку на $5 \ldots 10$ с. 


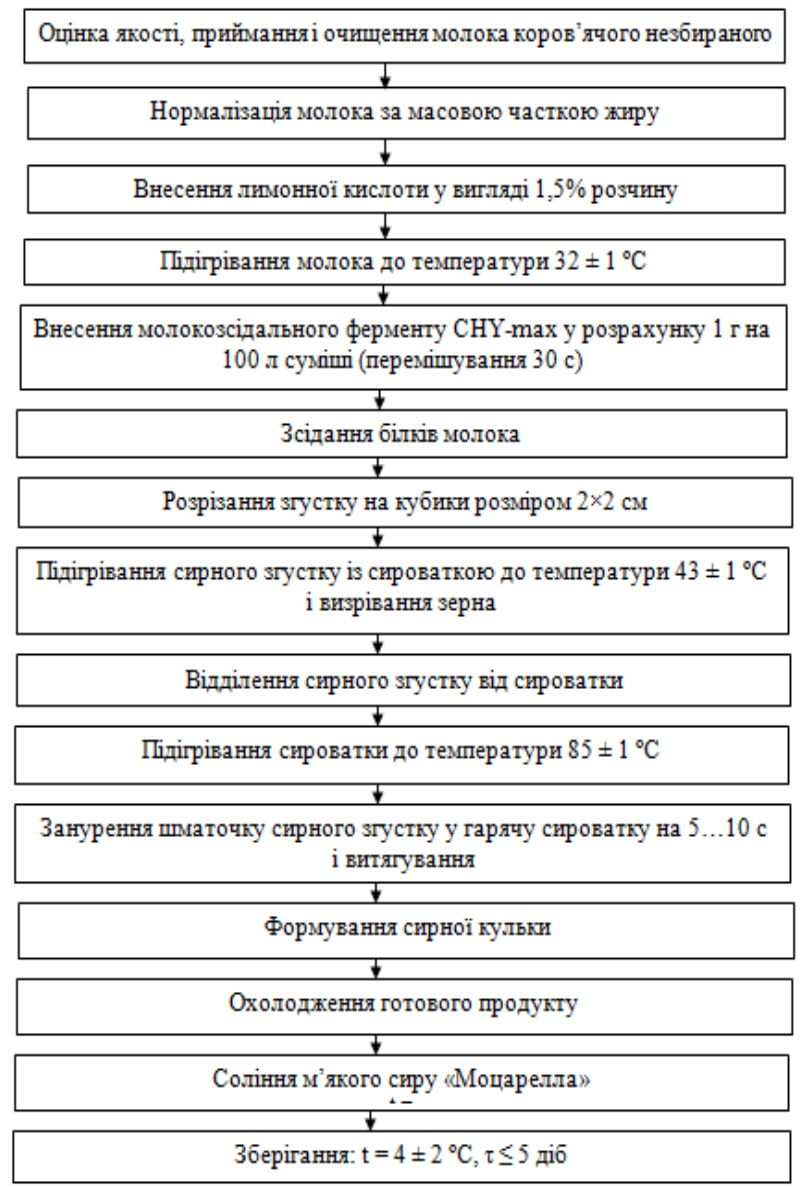

Рис. 1. Технологічна схема виробництва м'якого сиру «Моцарелла» із використанням для зсідання білків лимонної кислоти

Повторювали це кілька разів, формуючи еластичну сирну кульку. Частину сироватки охолоджували i використовували для зберігання м'якого сиру. Термін придатності сиру «Моцарелла» за температури зберігання $4 \pm 2{ }^{\circ} \mathrm{C}$ не більше ніж 5 діб.

При використанні для зсідання білків закваски прямого внесення запропоновано технологічну схему виробництва м'якого сиру «Моцарелла», що представлена на рисунку 2.

У охолоджену до температури $32 \pm 1{ }^{\circ} \mathrm{C}$ суміш вносили заквашувальну культуру прямого внесення RSF-742 у розрахунку 3,6 г на 100 л суміші, ферментний препарат CHY-max у розрахунку 1 г на 100 л молока та хлористий кальцій у вигляді 1\% розчину. Всі подальші технологічні операції аналогічні як і при використанні лимонної кислоти.

Тривалість зсідання нормалізованої суміші при виробництві сиру «Моцарелла» із використанням розчину лимонної кислоти становила 25 хв, що скорочується у 12 разів порівняно із використанням бактеріальної закваски (рис. 3). При використанні як коагулятора заквашувального препарату тривалість зсідання білків становила 5 год. За це період активна кислотність у цьому зразку знизилась з 6,65 до 4,68 од. $\mathrm{pH}$.

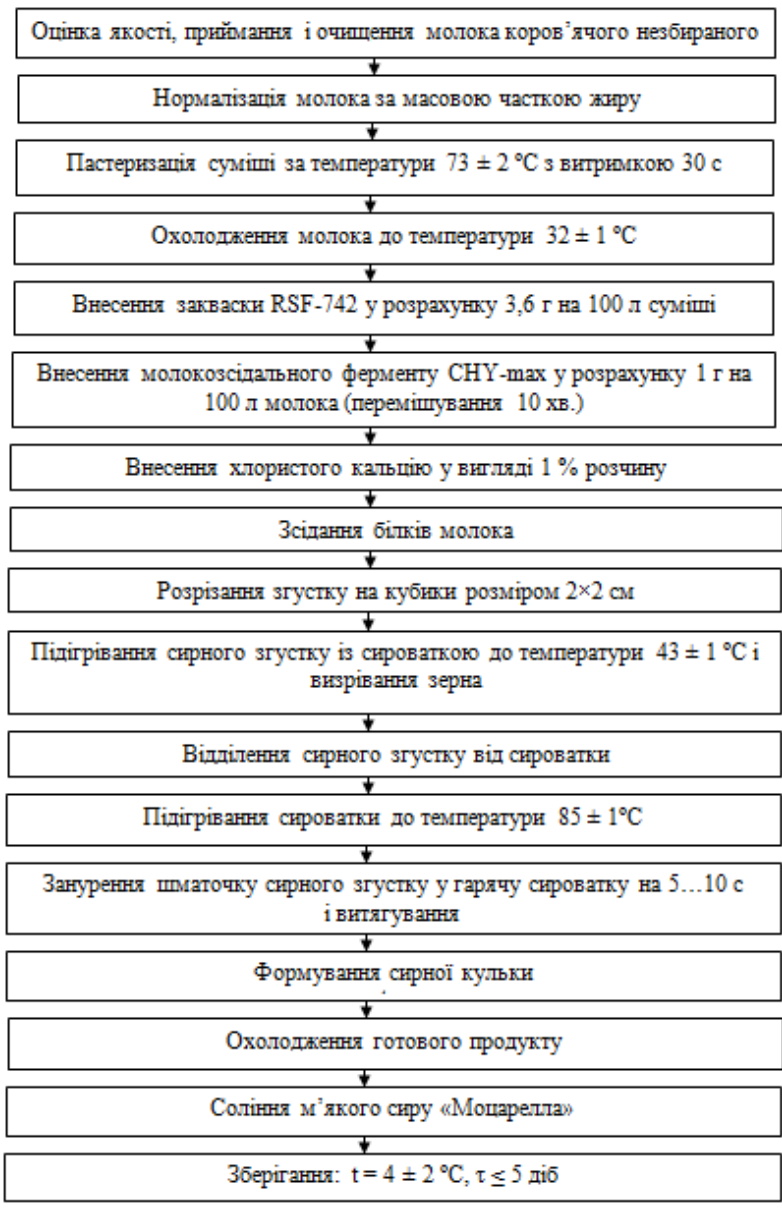

Рис. 2. Технологічна схема виробництва м'якого сиру «Моцарелла» із використанням для зсідання білків закваски прямого внесення

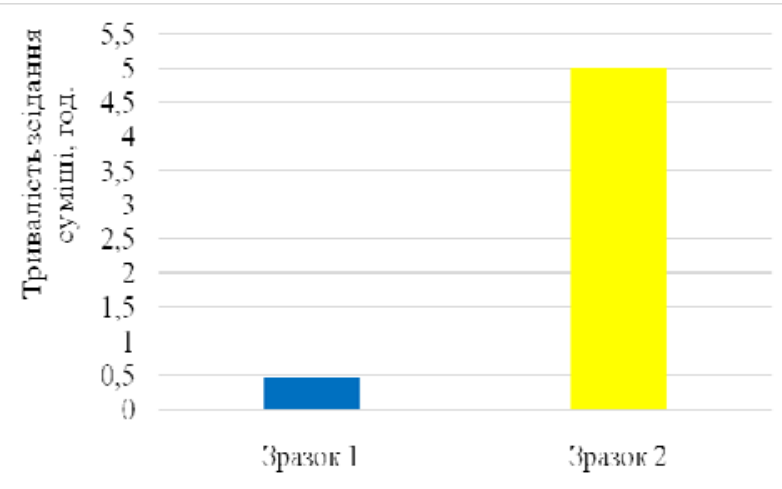

Рис. 3. Тривалість зсідання нормалізованої суміші при виробництві м'якого сиру «Моцарелла» із використанням різних способів зсідання білків

На рисунку 4 представлені результати досліджень синеретичних властивостей сичужних згустків. Дані проведених досліджень свідчать, що зразок 1, при зсіданні якого використовували розчин лимонної кислоти, має гірші синеретичні властивості порівняно 3 використанням заквашувального препарату прямого внесення RSF-742. Об'єм сироватки, що виділився за 1 год. для зразка 1 становив 49\%, тоді як для зразка 2 - $65 \%$ відповідно. 


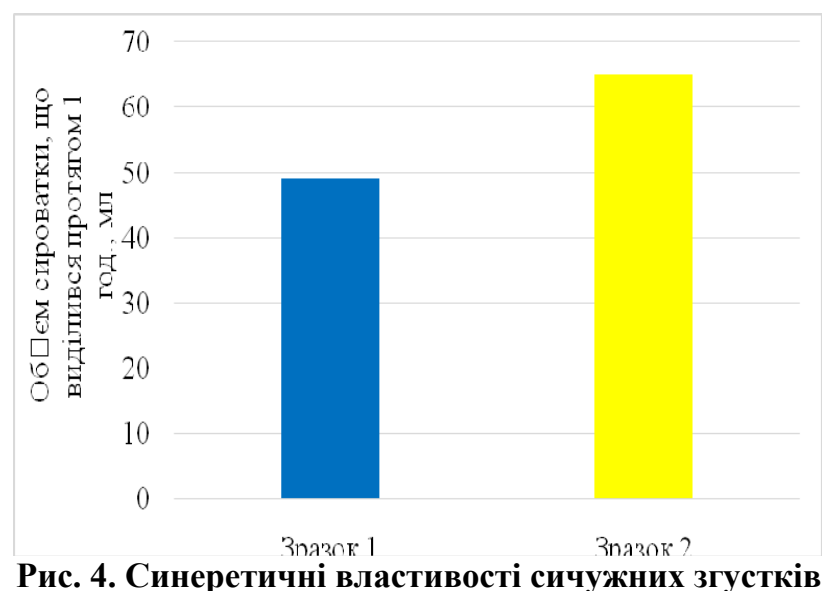

Різні способи зсідання білків молока при виробництві сирів суттево впливають на вихід готового продукту (Diduh and Avershina, 2010). При використанні заквашувального препарату прямого внесення RSF-742, є нижчий вихід сиру (385 г), аніж при використанні розчину лимонної кислоти, що пояснюється утворенням більшої кількості казеїнового пилу, який переходить до сироватки. Більший вихід цільового продукту у зразку 1 (420 г) відзначаємо при використанні розчину лимонної кислоти та сичужного ферменту CHY-max фірми «Хр. Хансен Україна» (рис. 5).

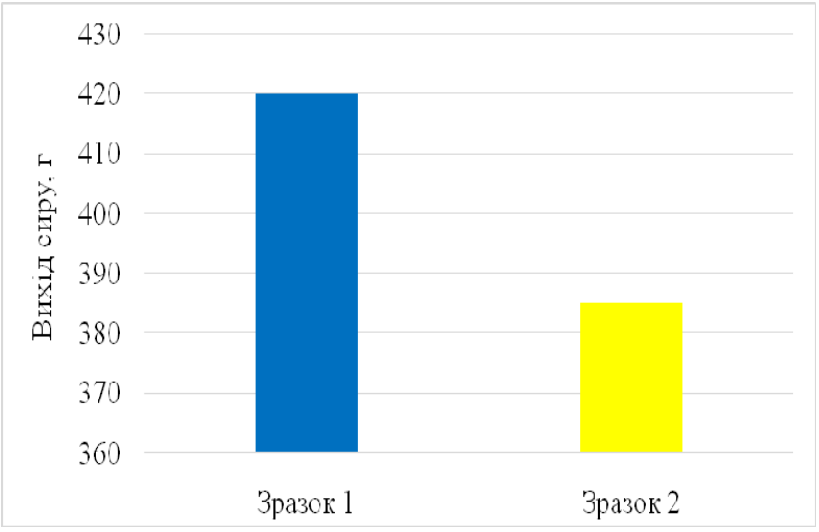

Рис. 5. Вихід готового продукту

Згідно органолептичної оцінки зразок 1 із використанням розчину лимонної кислоти характеризувався вираженим сирним, кисломолочним, без сторонніх присмаків та запахів, властивий м'якому свіжому сиру смаком і запахом; поверхня чиста без механічних пошкоджень, пружна, з відбитком перфорації; консистенція мазка, ніжна, в міру щільна; колір білий, рівномірний за всією масою; тісто 3 наявністю вічок. Гіршими органолептичними показниками характеризувався зразок 2 при використанні заквашувальної культури прямого внесення RSF-742. Він характеризувався вираженим сирним смаком; зовнішній вигляд - без відбитку перфорації; колір білий 3 кремовим відтінком; консистенція мазка, злегка крихка; тісто 3 наявністю невеликих пустот.

Відповідно до синеретичних властивостей зразок 1 характеризувався вищою масовою часткою вологи. За масовою часткою жиру у сухій речовині зразок 2 відзначався вищим значенням - 48\%, проти 44\% відповідно у зразку 1.

При внесенні різних коагулянтів у молоко при виробництві м'яких сирів змінилася титрована кислотність готового продукту. Вищим показником кислотності $\left(103^{\circ} \mathrm{T}\right)$ характеризувався зразок 2 при використанні заквашувальної культури прямого внесення RSF-742.

Для встановлення терміну зберігання м'якого сиру «Моцарелла» були проведені дослідження органолептичних та фізико-хімічних показників у процесі зберігання при температурі $(4 \pm 2){ }^{\circ} \mathrm{C}$ впродовж 5 діб. Упродовж перших трьох діб зберігання органолептичні показники обох зразків практично не змінювалися. При подальшому зберіганні, на 5 добу, у всіх зразках сиру спостерігався виражений гіркуватий смак та незначне виділення сироватки на поверхні сиру. Проблема всихання сирів є важливою (Daly, 1986). Що стосується масової частки вологи у виготовлених сирах, то у процесі їх зберігання вміст вологи знижується в обох досліджуваних зразках. Так, у зразку 1 при використанні розчину лимонної кислоти, масова частка вологи знизилася з 53 до 44\%, тоді як у зразку 2 масова частка вологи відповідно знизилася з 49 до $47 \%$. Найнижча величина титрованої кислотності за 5 діб зберігання була у зразку $2-115^{\circ} \mathrm{T}$.

\section{Висновки}

Тривалість зсідання нормалізованої суміші при виробництві сиру «Моцарелла» із використанням розчину лимонної кислотистановила 25 хв, що значно менше (у 12 разів) порівняно із використанням бактеріальної закваски, що значно пришвидшує технологічний процес.

При застосуванні лимонної кислоти збільшується на 9\% вихід сиру, тому з комерційною метою для отримання більшого прибутку доцільно використовувати лимонну кислоту.

Згідно органолептичної оцінки зразок із використанням лимонної кислоти характеризувався вираженим сирним, кисломолочним, без сторонніх присмаків та запахів, властивий м'якому свіжому сиру смаком i запахом, дещо гіршими органолептичними показниками був наділений зразок 3 використанням заквашувальної культури прямого внесення RSF-742.

Однак, під час зберігання зразок, для коагуляції білків якого використовували заквашувальну культуру прямого внесення RSF-742 характеризувався кращими органолептичними і фізико-хімічними показниками.

Перспективи подальших досліджень. В подальшому планується розроблення технології «Моцарелли» із застосуванням різних заквашувальних культур.

\section{Бібліографічні посилання}

Kalmykova, G.F. (2015). Rozroblennja tehnologii' syru termokyslotnogo, zbagachenogo molochnokysloju mikrofloroju. Dysertacija na zdobuttja naukovogo 
stupenja kandydata tehnichnyh nauk, Kyi'v (in Ukrainian).

Soda, M.El., Madkor, S.A., Tong, P.S. (2000). Marschall Rhodia International Dairy Science Award Lecture. Adjunct Cultures: Recent Development and Potential Significance to the Cheese Industry. Journal of Dairy Science. 83(5), 609-616.

Tkachenko, N.A., Skrypnichenko, D.M. (2016). Innovacijna tehnologija vyrobnyctva m'jakyh syriv z probiotychnymy vlastyvostjamy. Wschodnioeuropejskie Czasopismo Naukowe (East European Scientific Journal). 6, 99-107 (in Ukrainian).

Shergina, I.A. (2009). Osobennosti proizvodstva mjagkih syrov. Pererabotka moloka. 2, 30-31 (in Russian).

Mironenko, I.M., Usatjuk, D.A. (2015). Mjagkie syry. Assortiment i tehnologicheskie osobennosti. Syrodelie i maslodelie. 4, 36-40 (in Russian).

Musiy, L., Tsisaryk, O., Slyvka, I., Mykhaylytska, O., Gutyj, B. (2017). Research into probiotic properties of cultured butter during storing. Eastern-European Journal of Enterprise Technologies. 3, 11(87), 31-36.

Musiy, L., Tsisaryk, O., Slyvka, I., Mykhaylytska, O., Gutyj, B. (2017). Study of keeping probiotic properties of sour-cream butter at storage. EUREKA: Life Sciences. 2, 27-33.
Gudkov, A.V. (2004). Syrodelie: tehnologicheskie, biologicheskie i fiziko-himicheskie aspekty. M.: DeLi Print (in Russian).

Bannikova, L.A., Koroljova, N.S., Semenihina, V.F. (1987). Mikrobiologicheskie osnovy molochnogo proizvodstva: Spravochnik. M.: Agropromizdat (in Russian)

DSTU 3662-97 (1997). Moloko korov'jache nezbyrane. Vymogy pry zakupivli. Chynnyj vid 01.01.93. K.: Derzhstandart Ukrai'ny, 10 (in Ukrainian).

Diduh, N.A., Avershina, A.S. (2010). Vlijanie proteoliticheskih fermentov na razmer i srednjuju massu chastic kazeina $\mathrm{v}$ korov'em moloke. Novitni tekhnolohii, obladnannia, bezpeka ta yakist kharchovykh produktiv: sohodennia ta perspektyvy: Materialy Mizhnarodnoi naukovo-prktychnoi konferentsii, Kyiv (in Russian).

Daly, C. (1986). Starters: application in the dairy. Proceeding of the XXII International Dairy Congress «Milk - the vital force». The Hague, 95 -103.

Received 20.09.2017

Received in revised form 23.10.2017

Accepted 27.10.2017 